\title{
ANALYSIS OF DYNAMIC PORTFOLIO ALLOCATION OF INDONESIAN LQ45 DURING 2005 - 2011 FOLLOWING THE MARKOWITZ THEORY
}

\author{
Agustini Hamid \\ Accounting Department, Faculty of Economic and Comunication, Bina Nusantara University \\ Jln. K.H. Syahdan No 9, Palmerah, Jakarta Barat, 11480 \\ agustinihamid55@gmail.com
}

\begin{abstract}
The research observed that equity portfolio and investment managers were facing challenges in determining the optimum portfolio, especially during the turbulent times. As a result, they needed to implement portfolio management strategies to overcome the risk associated with stock return volatility in turbulence periods. This research focused on selecting stocks from the LQ-45 index during 2005-2011 using The Markowitz theory combining the Solver Linear Programming. The portfolio selection method which has been introduced by Markowitz (1952) used variance or standard deviation as a risk measurement. The result of this research proves that the composition of the portfolio is not the same in the different period. In the bearish period, the composition of the optimum portfolio is dominated by the banking sector and manufacture sector. In the bullish period, the optimum portfolio is dominated by the commodity stocks.
\end{abstract}

Keywords: dynamic portfolio, Markowitz theory, linear programming

\section{INTRODUCTION}

According to Bodie, Kane and Marcus (2009), an investment is the current commitment of money or other resources in the expectation of reaping future benefits. While, based on Horn in Bodie, Kane and Marcus (2009), investment is the activity conducted by utilizing current cash to get the return in the future. In essence, investment is postponing consumption to obtain the value or greater compensation in the future.

According to Bernstein and Damodaran (1998), the investment process consists of five steps to set investment goals. First, prescribing investment goals. The investment goals categorized based on the time horizon, whether it is for short, medium, or long term investment. Second, establish investment policy. How to distribute investment funds to a proper asset allocation. Third, choose portfolio strategy. Selecting portfolio strategy which consistent with the objectives and investment policy guidelines of the investor. The last step is measuring and evaluating portfolio performance. In this step, portfolio performance is measured and then evaluated periodically. The evaluation covers not only the expected return of the investment but also possible risks.

Equity portfolio and investment managers are facing challenges in determining the optimum portfolio, especially during the turbulent times. They need to implement portfolio management strategies to overcome the risk associated with stock return volatility in turbulence periods. Reilly and Brown (2009) have mentioned that it is important to allocate fund efficiently due to capital limitation. Portfolio managers could choose to invest in risk-free assets, risky assets, or the combination of both. Investment assets can be categorized into broad asset classes, such as stocks, bonds, real estate, commodities, and others. Asset allocation process is important. Asset allocation is categorized into 
two, passive asset allocation which based on the mean-variance framework (Markowitz portfolio) and active asset allocation which aimed to acquire profits from market movements. Switching investment allocation according to the market trends from overvalued assets to undervalued asset and vice versa is possible. Another strategy is to buy a call option if the market is expected to rise or otherwise buy a put option if the market is expected to decline.

To mitigate the risk due to stock market speculations, portfolio managers prefer to invest their portfolio in large market capitalization and liquid stocks. Active portfolio managers have their own preference of stocks in their portfolio; following their own terms and analysis, they pick stocks with large market capitalization and actively traded stocks. On the contrary, passive managers do not pick stocks and do research on portfolio allocation. Instead, they take the stocks from the index and allocate them following the allocation in the index as decided by the index manager. For instance, if the passive managers decided to follow the LQ-45, they will select stocks from the LQ-45 list and weight the allocation following their respective allocations in the LQ-45. In Indonesia, passive portfolio managers prefer to invest in LQ-45 stocks because the stocks have big market capitalization and liquid stocks.

The main objective of investors when investing in an equity mutual fund (reksadana saham) is to get the maximum return from their investments. However, rational investors want to maximize return and minimize risk. Unfortunately, it is difficult to minimize risk of portfolio that has $80 \%$ equity allocation or more during financial downturns. Data shows that all reksadana saham posted negative return during the 2008 financial crisis, and at least $50 \%$ of them performed worse compare to Jakarta Composite Index (JCI) and index liquid 45 (LQ-45)

In 1952, Harry Markowitz developed the portfolio theory. Prior to his article, he has mentioned the necessity of improvements on theory of money in 1935. He introduced risk in his analysis and stated that the risk-factor comes into problem in two ways. First, risk-factor may affect the expected period of investment, and second, risk-factor may affect the expected net yield of investment. Modern Portfolio Theory (MPT) or portfolio theory was introduced by Harry Markowitz in 1952. The theory focused on assessing the risks and returns of individual securities in construction their portfolios.

Gallati (2003) has also mentioned in his book that he could not demonstrate a formula relating risk of individual assets to risk of the portfolio as the whole. Since this work is based on MPT, he will consider the model developed by Markowitz and his work on mean-variance analysis. He states that the expected return (mean) and variance of returns of a portfolio are the whole criteria for portfolio selection. These two parameters can be used as a possible hypothesis about actual behavior and a maxim for how investors ought to act.

Fabozzi, Francis and Markowitz (2002b) have illustrated several common asset allocations, portfolio management, and portfolio construction in his journal, picturing that it is valid to expect that MPT will occupy a permanent place in the development of theory and practices of finance portfolio. Building a stock portfolio is the difficult task because the characteristic of individual stocks contain uncertainty. Therefore, a benchmark is needed and calculation to determine portfolio performance must be performed. Based on the background, the research is about analysis dynamic portfolio allocation of Indonesia LQ-45 stocks following the Markowitz theory. 


\section{METHODS}

In 1952, Harry Markowitz developed the portfolio theory. Prior to his article, he mentioned the necessity of improvements on the theory of money in 1935. He has introduced risk in his analysis and stated that the risk-factor comes into the problem in two ways. First, risk-factor may affect the expected period of investment, and second, risk-factor may affect the expected net yield of the investment.

Markowitz model relies on the following assumptions: (1) Investors seek to maximize the expected return of total wealth, (2) All investors have the same expected single period investment horizon, (3) All investors are risk-averse, that is they will only accept a higher risk if they are compensated with a higher expected return, (4) Investors base their investment decisions on the expected return and risk, (5) All markets are perfectly efficient. Diversification reduces risks on a portfolio. Diversification can be loosely measured by some statistical measurement, intra-portfolio correlation. It has a range of -1 to 1 and measures the degree to which the various asset in a portfolio can be expected to perform in a similar fashion or not. Markowitz model suggests that it is possible to reduce the level of risk below the diversifiable risk.

The risk is defined in terms of loss, exposure to the chance of injury or loss; a hazard or dangerous chance. But, a more appropriate definition of risk for investors is the uncertainty of expected returns. Most investors think of risk as some loss. The potential for loss is also the reason they earn a return. Loss aversion refers to the concept that the pain of losing a sum of money is greater than the pleasure of gaining the same amount of money. This is incorporated into the optimization process that uses risk and return trade-offs of different asset classes to build portfolios.

Based on Markowitz theory, the expected returns for a portfolio is simply the weighted average of the expected rate of returns for the individual investments in the portfolio. The weights are the proportion of total value of the individual investment. The expected rate of return for a portfolio is simply the weighted average of the expected rates of return for the individual asset in the portfolio. The weights are the proportion of total value for the individual asset. To calculate the portfolio return, the general formula is defined as

$$
E(R i)=\sum_{i=1}^{n}(w i)(R i)
$$

Where:

$\mathrm{W}_{\mathrm{i}}=$ the weight of an individual asset in the portfolio or the percent of the portfolio in Asset $\mathrm{i}$

$\mathrm{R}_{\mathrm{i}}=$ the expected rate of return for Asset $\mathrm{i}$

Fabozzi et al. (2002a) have mentioned that risk is the chance or possibility that investors face from their investments. According to Chen et al. (2009), risk has two components; they are the systematic and unsystematic risk. According to Markowitz (1959), portfolio risk is influenced by the weighted average of each individual asset risk and the covariance between assets that make up the portfolio. The variance and standard deviation of returns are common measures of risk. Standard deviation is used to calculate the risk of realized return while risk from expected return is used variance as the measurement.

$$
\operatorname{VAR}\left(R_{p}\right)=\sum_{i=1}^{N} \sum_{j=1}^{N} x_{i} x_{j} \sigma_{i j}
$$

Where:

$\sigma_{\mathrm{ij}}=\sigma_{\mathrm{i}} \sigma_{\mathrm{j}} \rho_{\mathrm{ij}}$ and $\rho_{\mathrm{ij}}$ is correlation coefficient between assets $i$ and $j$. 
According to Markowitz (2011), Variance or standard deviation of returns is common measure of investment risk. Both of these are measure of the variability of a distribution of returns about its mean or expected value. The variance or standard deviation is a measure of the variation of possible rates of return $\mathrm{Ri}$ from the expected rate of return $\mathrm{E}\left(\mathrm{R}_{\mathrm{i}}\right)$ as follows:

$$
\sigma^{2}=\sum_{i=1}^{n}[R i-E(R i)]_{2 \mathrm{Pi}}
$$

Where $\mathrm{P}_{\mathrm{i}}$ is probability of the possible rate of return $\mathrm{R}_{\mathrm{i}}$.

$$
\text { Standard Deviation } \quad=\sigma=\sqrt{\sum_{i-1}^{n}[R i-E(R i)]^{2} \mathrm{Pi}}
$$

Brigham and Daves (2010) have defined that efficient portfolio is the combination of investment that gives same return with minimal risk. The efficient frontier emphasizes a geometric interpretation of asset combinations. In this frontier, a market portfolio will be allocated which should be preferred by all investors, under the assumptions that all investors are risk averse and prefer more return to less. Figure 1 shows the efficient frontier line.

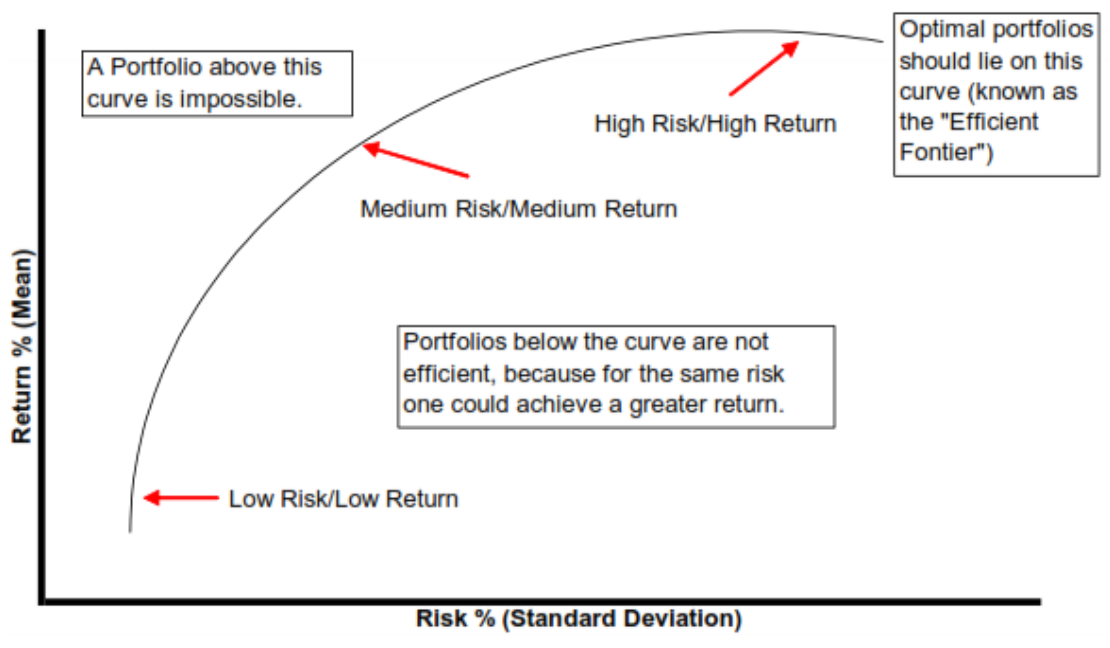

Figure 1 The Efficient Frontier Line

To calculate the weighting of any stocks that are used in a portfolio, first, we must determine the minimum and maximum limits of the average return. Mean-Variance formula is to obtain the expected return, variance and standard deviation of the portfolio. Linear programming by solver excel is used to find each weight of stocks in one portfolio. The Solver requires changing cells, a target cell for minimization and the specification of constraints, which acts as the restriction on feasible values for the changing cells. The target cell is to minimize the standard deviation of return for will focuses on the composition of shares that give the minimum risk. The model consists of following components, such as decision variables, objective function, and constraints.

The decision of the problem is represented using symbols such as X1, X2, X3, Xn. These variables represent unknown quantities (number of items to produce, weighted of shares to invest). The objective of the problem is expressed as a mathematical expression in decision variables. The objective of the research is minimizing the risk. 
Minimize

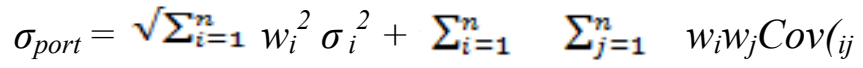

$$
\begin{aligned}
& \text { ○ }) i \neq j
\end{aligned}
$$

The constraints of the limitation or requirements of the problem are expressed as inequalities or equations in decision variables.

$$
\text { 1. } \sum_{i=1}^{n}(w i)(\mathrm{Ri})-R p \geq 0
$$

The total multiplication of weighted shares and expected return of each stock are equal with portfolio return. The total proportion of all shares in portfolio are equal one.

$$
\text { 2. } \sum_{i=1}^{n}(w i)-1=0
$$

Constructing equity portfolio needs complicated process, especially when higher return portfolio is required. By using the Markowitz Theory, first is calculating the expected returns, standard deviation, and variance of stocks. The next step is to compute correlation and covariance which measure the degree of two variables move together about their individual means during the same period. After covariance has been computed, the standard deviation of the portfolio can be calculated. Next step, the stocks will be mixed into set portfolio using the formula mean-variance above combined with linear programming (solver excel). To determine the optimum portfolio, this research will calculate Risk-Adjusted Return (RAR) which divided portfolio return with standard deviation.

The Samples of data will be retrieved from IDX, which consist of stocks that are included in LQ-45 index. The stock list of LQ-45 announced every second quarter of each year. The Markowitz theory requires the sample to have positive expected return E(Ri). Period of research is 2005 up to 2011. In this period, Indonesia has experienced several market trends. In 2006 to 2007, Indonesia was in the upward moving market trend (bullish) and downward moving market trend (bearish) during 2008 until the beginning of 2009. The recovery period started at the end of 2009. In 2010, the market posted the highest return. The market is still favorable in 2011, indicated by JCI index was closed at 3821.992 at the end of the year. It means that the data taken from this period are representing Indonesian stock market in all condition.

Population for this research is LQ-45 stocks during 2005-201. Amongst this population, there are 16 stocks that have positive expected return in bullish period while there are 12 stocks in bearish period. All of them can be seen in Table 1. 
Table 1 List of 16 Stocks

\begin{tabular}{|c|c|c|c|c|c|}
\hline No. & Name of the company & $\begin{array}{l}\text { IDX } \\
\text { Code }\end{array}$ & Sector & $\begin{array}{l}\text { Shares } \\
\text { ( in mn) }\end{array}$ & $\begin{array}{c}\text { Index Weight } \\
(\%)\end{array}$ \\
\hline 1 & PT Astra International Tbk & ASII & Automotive & $40,483.55$ & 11.96 \\
\hline 2 & PT Bank Central Asia Tbk & BBCA & Banking (Finance) & $24,408.46$ & 7.80 \\
\hline 3 & PT Bank Mandiri Tbk & BMRI & Banking (Finance) & $23,100.00$ & 7.18 \\
\hline 4 & PT Telekomunikasi Indonesia Tbk & TLKM & Telecommunication & $20,160.00$ & 6.88 \\
\hline 5 & PT Bank Rakyat Indonesia Tbk & BBRI & Banking (Finance) & $24,422.47$ & 6.52 \\
\hline 6 & PT Perusahaan Gas Negara Tbk & PGAS & Utility & $24,241.51$ & 3.74 \\
\hline 7 & PT United Tractor Tbk & UNTR & Heavy Equipment & $3,730.14$ & 3.68 \\
\hline 8 & PT Bank Danamon Tbk & BDMN & Banking (Finance) & $9,488.80$ & 2.43 \\
\hline 9 & PT Indofood Sukses Makmur Tbk & INDF & Consumer Goods & $8,780.43$ & 1.86 \\
\hline 10 & PT Astra Agro Lestari Tbk & AALI & Agriculture & $1,574.74$ & 1.46 \\
\hline 11 & PT Tambang Batubara Bukit Asam Tbk & PTBA & Mining & $2,304.13$ & 1.42 \\
\hline 12 & PT Vale indonesia Tbk & INCO & Mining & $9,936.34$ & 1.02 \\
\hline 13 & PT Indosat Tbk & ISAT & Telecommunication & $5,433.90$ & 0.59 \\
\hline 14 & PT Aneka Tambang Tbk & ANTM & Mining & $9,538.46$ & 0.55 \\
\hline 15 & PT Medco International Tbk & MEDC & Mining & $3,332.50$ & 0.18 \\
\hline 16 & PT Bakrie Sumatera Plantation Tbk & UNSP & Agriculture & $13,720.47$ & 0.10 \\
\hline
\end{tabular}

\section{RESULTS AND DISCUSSIONS}

Table 2 indicates the calculation of the expected return, variance and standard deviation in bearish period. There are 12 stocks that included in bearish period, while there are 16 selected stocks in bullish period.

Table 2 The Expected Return, Variance, Standard Deviation in Bearish Period and Bullish Period

\begin{tabular}{|c|c|c|c|c|c|c|c|}
\hline Stocks & E(Ri) & Var & $\boldsymbol{\sigma}$ & Stocks & $\begin{array}{c}\text { E(Ri) } \\
\text { (Monthly) }\end{array}$ & Var & $\boldsymbol{\sigma}$ \\
\hline & (Monthly) & & & UNTR & $6.7 \%$ & $2.3 \%$ & $15.1 \%$ \\
\hline BMRI & $5.9 \%$ & $4.6 \%$ & $21.3 \%$ & $\begin{array}{l}\text { ANTM } \\
\text { AALI }\end{array}$ & $\begin{array}{l}6.5 \% \\
6.1 \%\end{array}$ & $\begin{array}{l}1.0 \% \\
1.3 \%\end{array}$ & $\begin{array}{l}10.2 \% \\
11.6 \%\end{array}$ \\
\hline ASII & $5.7 \%$ & $2.1 \%$ & $14.5 \%$ & INCO & $5.6 \%$ & $1.1 \%$ & $10.3 \%$ \\
\hline UNTR & $5.5 \%$ & $6.4 \%$ & $25.3 \%$ & PGAS & $5.5 \%$ & $1.1 \%$ & $10.6 \%$ \\
\hline BDMN & $5.2 \%$ & $5.1 \%$ & $227 \%$ & INDF & $4.8 \%$ & $1.0 \%$ & $9.9 \%$ \\
\hline & & & 22.170 & PTBA & $4.5 \%$ & $0.5 \%$ & $7.3 \%$ \\
\hline BBRI & $4.7 \%$ & $4.1 \%$ & $20.3 \%$ & BMRI & $3.4 \%$ & $1.6 \%$ & $12.8 \%$ \\
\hline BBCA & $4.2 \%$ & $6.3 \%$ & $25.0 \%$ & TLKM & $2.6 \%$ & $1.6 \%$ & $12.5 \%$ \\
\hline PGAS & $3.9 \%$ & $4.5 \%$ & $21.2 \%$ & BBCA & $2.2 \%$ & $1.0 \%$ & $10.2 \%$ \\
\hline TLKM & $2.4 \%$ & $4.8 \%$ & $21.8 \%$ & ASII & $1.9 \%$ & $1.7 \%$ & $13.1 \%$ \\
\hline INDF & $1.9 \%$ & $3.2 \%$ & $17.8 \%$ & MEDC & $1.5 \%$ & $1.4 \%$ & $11.9 \%$ \\
\hline PTBA & $1.3 \%$ & $5.3 \%$ & $23.0 \%$ & BBRI & $1.3 \%$ & $2.0 \%$ & $14.0 \%$ \\
\hline INCO & $0.4 \%$ & $1.6 \%$ & $12.6 \%$ & ISAT & $1.3 \%$ & $0.5 \%$ & $7.3 \%$ \\
\hline AALI & $0.3 \%$ & $6.8 \%$ & $26.0 \%$ & UNTR & $0.8 \%$ & $1.9 \%$ & $13.9 \%$ \\
\hline
\end{tabular}

In this research, the decision variables are the weight of stocks that should be invested in bearish and bullish period. In bearish period, there are 12 stocks that have positive expected return. There are AALI, ASII, BBCA, BBRI, BDMN, BMRI, INCO, INDF, PGAS, PTBA, TLKM, and UNTR. While, there are 16 stocks that have positive return in bullish period. There are AALI, ANTM, ASII, BBCA, BBRI, BDMN, BMRI, INCO, INDF, ISAT, MEDC, PGAS, PTBA, TLKM, UNSP and UNTR. The research will calculate the proportion of each shares in portfolio. 


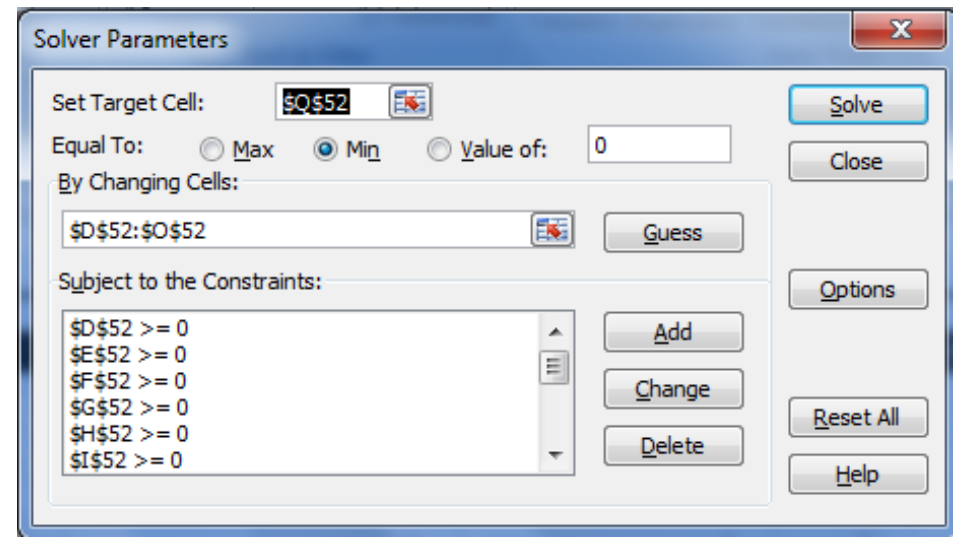

Figure 2 Solver Parameters

Figure 2 shows that the calculation weight of shares in the bearish period. Figure 2 shows that Q52 is the portfolio variance. D52 - O52 is the weight of each stock in the portfolio, P52 is the sum of weights, and R52 is the expected return of the portfolio. It shows that set target cell is the objective of the solver (\$Q52\$) which in this case is to minimize the variance of a portfolio. Changing cell refers to the weight of the stocks in a portfolio (\$D\$52:\$O52). The sum of the weights will be constrained to 1 (\$P\$52=1), and it means that each weight of stocks has to be zero or more $(\$ D \$ 52:: \$ O \$ 52>=0)$. The weight of stocks can change depend on the expected return that been set.

After calculation $\mathrm{E}(\mathrm{Ri})$, variance and standard deviation of each stock in the bearish period and bullish period use the linear solver programming, the optimum portfolio (Rp) that lies in Portfolio $\mathrm{F}$ in bearish. While in the bullish period, the optimum portfolio lies in Portfolio J. The matrix optimum portfolio of each period can be seen in Table 3 and Table 4.

Table 3 Optimum Portfolio Construction in Bearish Period

\begin{tabular}{|c|c|c|c|c|c|c|c|c|c|c|c|c|c|c|c|c|}
\hline Portfolio & AALI & ASII & BBCA & BBRI & BDMN & BMRI & INCO & INDF & PGAS & PTBA & TLKM & UNTR & SUM & STDEV & $\begin{array}{c}\text { RETURN } \\
\text { PORTFOLIO }\end{array}$ & RAR \\
\hline A & $73.1 \%$ & $0.0 \%$ & $0.0 \%$ & $0.0 \%$ & $0.0 \%$ & $0.0 \%$ & 0.268686 & $0.0 \%$ & $0.0 \%$ & $0.0 \%$ & $0.0 \%$ & $0.0 \%$ & $100.0 \%$ & $19.5 \%$ & $0.3 \%$ & 0.015353 \\
\hline B & $50.1 \%$ & $0.0 \%$ & $0.0 \%$ & $0.0 \%$ & $0.0 \%$ & $0.0 \%$ & $42.3 \%$ & $0.0 \%$ & $0.0 \%$ & $7.6 \%$ & $0.0 \%$ & $0.0 \%$ & $100.0 \%$ & $16.6 \%$ & $0.4 \%$ & 0.024113 \\
\hline C & $21.3 \%$ & $0.0 \%$ & $0.0 \%$ & $0.0 \%$ & $0.0 \%$ & $0.0 \%$ & $19.8 \%$ & $13.6 \%$ & $0.0 \%$ & $17.4 \%$ & $27.9 \%$ & $0.0 \%$ & $100.0 \%$ & $9.6 \%$ & $1.3 \%$ & 0.136117 \\
\hline D & $14.2 \%$ & $0.0 \%$ & $7.7 \%$ & $1.1 \%$ & $0.0 \%$ & $0.0 \%$ & $13.5 \%$ & $12.2 \%$ & $6.8 \%$ & $13.3 \%$ & $31.0 \%$ & $0.0 \%$ & $100.0 \%$ & $7.8 \%$ & $1.9 \%$ & 0.244586 \\
\hline$E$ & $10.8 \%$ & $1.1 \%$ & $11.9 \%$ & $4.1 \%$ & $2.5 \%$ & $0.4 \%$ & $10.3 \%$ & $10.4 \%$ & $8.8 \%$ & $10.7 \%$ & $27.8 \%$ & $1.1 \%$ & $100.0 \%$ & $6.9 \%$ & $2.4 \%$ & 0.350135 \\
\hline$F$ & $2.8 \%$ & $8.9 \%$ & $17.5 \%$ & $8.6 \%$ & $7.6 \%$ & $9.0 \%$ & $2.8 \%$ & $5.2 \%$ & $10.9 \%$ & $4.2 \%$ & $16.7 \%$ & $5.8 \%$ & $100.0 \%$ & $6.5 \%$ & $3.9 \%$ & 0.601683 \\
\hline G & $1.2 \%$ & $10.5 \%$ & $18.6 \%$ & $9.5 \%$ & $8.6 \%$ & $10.7 \%$ & $1.4 \%$ & $4.1 \%$ & $11.3 \%$ & $2.8 \%$ & $14.5 \%$ & $6.7 \%$ & $100.0 \%$ & $6.9 \%$ & $4.2 \%$ & 0.612902 \\
\hline $\mathrm{H}$ & $0.0 \%$ & $19.9 \%$ & $15.8 \%$ & $11.8 \%$ & $13.2 \%$ & $21.6 \%$ & $0.0 \%$ & $0.0 \%$ & $6.0 \%$ & $0.0 \%$ & $0.0 \%$ & $11.8 \%$ & $100.0 \%$ & $9.2 \%$ & $5.2 \%$ & 0.563628 \\
\hline I & $0.0 \%$ & $26.3 \%$ & $4.2 \%$ & $10.2 \%$ & $14.9 \%$ & $29.7 \%$ & $0.0 \%$ & $0.0 \%$ & $0.0 \%$ & $0.0 \%$ & $0.0 \%$ & $14.7 \%$ & $100.0 \%$ & $10.9 \%$ & $5.5 \%$ & 0.503465 \\
\hline J & $0.0 \%$ & $32.6 \%$ & $0.0 \%$ & $0.0 \%$ & $11.6 \%$ & $39.7 \%$ & $0.0 \%$ & $0.0 \%$ & $0.0 \%$ & $0.0 \%$ & $0.0 \%$ & $16.0 \%$ & $100.0 \%$ & $12.7 \%$ & $5.7 \%$ & 0.449782 \\
\hline K & $0.0 \%$ & $10.5 \%$ & $0.0 \%$ & $0.0 \%$ & $0.0 \%$ & $89.5 \%$ & $0.0 \%$ & $0.0 \%$ & $0.0 \%$ & $0.0 \%$ & $0.0 \%$ & $0.0 \%$ & $100.0 \%$ & $19.3 \%$ & $5.9 \%$ & 0.306333 \\
\hline
\end{tabular}


Table 4 Optimum Portfolio Construction in Bullish Period

\begin{tabular}{|c|c|c|c|c|c|c|c|c|c|c|c|c|c|c|c|c|c|c|c|c|}
\hline itfolio & AALI & ANTM & ASII & $\mathrm{BBCA}$ & BBRI & BDMN & BMRI & INCO & INDF & ISAT & MEDC & PGAS & PTBA & TLKM & UNSP & UNTR & SUM & STDEV & $\begin{array}{l}\text { RETURN } \\
\text { PORTFOLIO }\end{array}$ & RAR \\
\hline A & $0.0 \%$ & $0.0 \%$ & $0.0 \%$ & $0.0 \%$ & $0.0 \%$ & 91.9\% & $0.0 \%$ & $0.0 \%$ & $0.0 \%$ & $8.1 \%$ & $0.0 \%$ & $0.0 \%$ & $0.0 \%$ & $0.0 \%$ & $0.0 \%$ & $0.0 \%$ & $100.0 \%$ & $9.5 \%$ & $0.7 \%$ & 0.07350 \\
\hline B & $0.0 \%$ & $0.0 \%$ & $0.0 \%$ & $0.0 \%$ & $0.0 \%$ & $43.3 \%$ & $0.0 \%$ & $0.0 \%$ & $0.0 \%$ & $45.7 \%$ & $0.0 \%$ & $0.0 \%$ & $0.0 \%$ & $11.0 \%$ & $0.0 \%$ & $0.0 \%$ & $100.0 \%$ & $6.2 \%$ & $0.8 \%$ & 0.12883 \\
\hline C & $0.0 \%$ & $0.0 \%$ & $2.4 \%$ & $20.3 \%$ & $6.1 \%$ & $18.1 \%$ & $6.3 \%$ & $0.0 \%$ & $0.0 \%$ & $21.6 \%$ & $0.0 \%$ & $0.0 \%$ & $0.0 \%$ & $25.2 \%$ & $0.0 \%$ & $0.0 \%$ & $100.0 \%$ & $3.8 \%$ & $1.2 \%$ & 0.31507 \\
\hline D & $0.0 \%$ & $0.0 \%$ & $4.6 \%$ & $20.1 \%$ & $7.4 \%$ & $15.5 \%$ & $7.9 \%$ & $0.0 \%$ & $0.0 \%$ & $18.7 \%$ & $2.3 \%$ & $0.0 \%$ & $0.0 \%$ & $23.5 \%$ & $0.0 \%$ & $0.0 \%$ & $100.0 \%$ & $3.6 \%$ & $1.3 \%$ & 0.36315 \\
\hline $\mathrm{E}$ & $0.0 \%$ & $0.0 \%$ & $6.8 \%$ & $19.0 \%$ & $8.4 \%$ & $12.0 \%$ & $9.3 \%$ & $0.0 \%$ & $2.9 \%$ & $14.9 \%$ & $5.3 \%$ & $0.0 \%$ & $0.0 \%$ & $20.8 \%$ & $0.0 \%$ & $0.7 \%$ & $100.0 \%$ & $3.3 \%$ & $1.5 \%$ & 0.45087 \\
\hline$F$ & $1.0 \%$ & $0.0 \%$ & $6.6 \%$ & $16.8 \%$ & $7.8 \%$ & $10.0 \%$ & $8.8 \%$ & $2.0 \%$ & $3.8 \%$ & $12.5 \%$ & $5.4 \%$ & $2.0 \%$ & $0.6 \%$ & $18.2 \%$ & $1.0 \%$ & $3.5 \%$ & $100.0 \%$ & $3.1 \%$ & $1.9 \%$ & 0.61515 \\
\hline G & $2.6 \%$ & $0.5 \%$ & $6.3 \%$ & $15.4 \%$ & $7.3 \%$ & $8.8 \%$ & $8.4 \%$ & $2.7 \%$ & $4.0 \%$ & $11.1 \%$ & $5.3 \%$ & $3.0 \%$ & $1.7 \%$ & $16.7 \%$ & $1.7 \%$ & $4.6 \%$ & $100.0 \%$ & $3.0 \%$ & $2.2 \%$ & 0.73518 \\
\hline H & $4.6 \%$ & $1.7 \%$ & $5.8 \%$ & $13.5 \%$ & $6.6 \%$ & $7.3 \%$ & $7.8 \%$ & $3.5 \%$ & $4.2 \%$ & $9.3 \%$ & $5.1 \%$ & $4.2 \%$ & $3.2 \%$ & $14.6 \%$ & $2.6 \%$ & $5.9 \%$ & $100.0 \%$ & $3.0 \%$ & $2.6 \%$ & 0.87710 \\
\hline 1 & $8.5 \%$ & $4.2 \%$ & $5.0 \%$ & $9.7 \%$ & $5.3 \%$ & $4.3 \%$ & $6.6 \%$ & $5.2 \%$ & $4.7 \%$ & $5.8 \%$ & $4.7 \%$ & $6.7 \%$ & $6.0 \%$ & $10.5 \%$ & $4.3 \%$ & $8.5 \%$ & $100.0 \%$ & $3.2 \%$ & $3.4 \%$ & 1.04793 \\
\hline J & $13.8 \%$ & $7.5 \%$ & $3.9 \%$ & $4.5 \%$ & $3.5 \%$ & $0.2 \%$ & $5.0 \%$ & $7.5 \%$ & $5.3 \%$ & $0.9 \%$ & $4.2 \%$ & $10.0 \%$ & $9.9 \%$ & $4.9 \%$ & $6.7 \%$ & $12.1 \%$ & $100.0 \%$ & $4.2 \%$ & $4.5 \%$ & 1.07753 \\
\hline K & $15.4 \%$ & $8.5 \%$ & $3.4 \%$ & $2.7 \%$ & $2.7 \%$ & $0.0 \%$ & $4.4 \%$ & $8.1 \%$ & $5.5 \%$ & $0.0 \%$ & $3.9 \%$ & $11.0 \%$ & $11.1 \%$ & $2.9 \%$ & $7.4 \%$ & $13.1 \%$ & $100.0 \%$ & $4.5 \%$ & $4.8 \%$ & 1.06665 \\
\hline L & $19.6 \%$ & $11.4 \%$ & $0.4 \%$ & $0.0 \%$ & $0.0 \%$ & $0.0 \%$ & $0.5 \%$ & $9.3 \%$ & $5.0 \%$ & $0.0 \%$ & $2.0 \%$ & $13.3 \%$ & $14.4 \%$ & $0.0 \%$ & $9.1 \%$ & $15.0 \%$ & $1000 \%$ & $5.4 \%$ & $5.5 \%$ & 1.02482 \\
\hline M & $20.4 \%$ & $12.0 \%$ & $0.0 \%$ & $0.0 \%$ & $0.0 \%$ & $0.0 \%$ & $0.0 \%$ & $9.3 \%$ & $4.3 \%$ & $0.0 \%$ & $0.8 \%$ & $13.6 \%$ & $15.3 \%$ & $0.0 \%$ & $9.4 \%$ & $14.9 \%$ & $100.0 \%$ & $5.5 \%$ & $5.6 \%$ & 1.01622 \\
\hline $\mathbf{N}$ & $27.8 \%$ & $18.5 \%$ & $0.0 \%$ & $0.0 \%$ & $0.0 \%$ & $0.0 \%$ & $0.0 \%$ & $3.0 \%$ & $0.0 \%$ & $0.0 \%$ & $0.0 \%$ & $13.7 \%$ & $24.3 \%$ & $0.0 \%$ & $10.5 \%$ & $2.2 \%$ & $100.0 \%$ & $6.6 \%$ & $6.1 \%$ & 0.91741 \\
\hline 0 & $18.1 \%$ & $31.9 \%$ & $0.0 \%$ & $0.0 \%$ & $0.0 \%$ & $0.0 \%$ & $0.0 \%$ & $0.0 \%$ & $0.0 \%$ & $0.0 \%$ & $0.0 \%$ & $0.0 \%$ & $50.0 \%$ & $0.0 \%$ & $0.0 \%$ & $0.0 \%$ & $100.0 \%$ & $9.1 \%$ & $6.5 \%$ & 0.71081 \\
\hline $\mathbf{P}$ & $0.0 \%$ & $29.0 \%$ & $0.0 \%$ & $0.0 \%$ & $0.0 \%$ & $0.0 \%$ & $0.0 \%$ & $0.0 \%$ & $0.0 \%$ & $0.0 \%$ & $0.0 \%$ & $0.0 \%$ & $71.0 \%$ & $0.0 \%$ & $0.0 \%$ & $0.0 \%$ & $100.0 \%$ & $11.1 \%$ & $6.6 \%$ & 0.59433 \\
\hline
\end{tabular}

The optimum portfolio lies in efficient frontier. In bearish period, portfolio $\mathrm{G}$ is the optimum portfolio because the portfolio has higher RAR than others. While in bullish period, portfolio $J$ is the optimum portfolio that higher RAR. The RAR points of bearish and bullish period are 0,6129 and 1,07753. The efficient frontier curve in each period can be seen in Figure 3 and Figure 4.

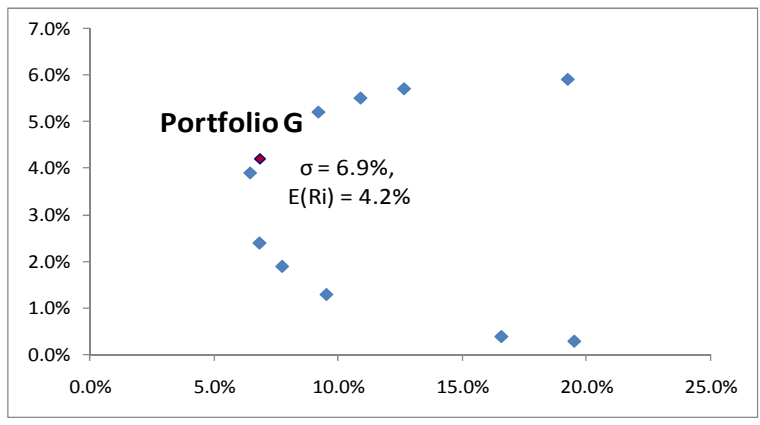

Figure 3 The Efficient Frontier Curve in Bearish Period

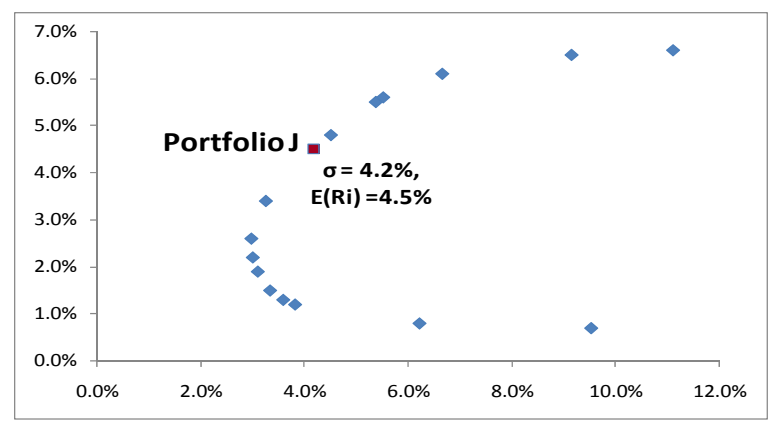

Figure 4 The Efficient Frontier Curve in Bullish Period

The optimal portfolio is selected portfolio that lies on efficient portfolio. To prove it, the calculation of portfolio return is shown on Table 5 and Table 6 .

Table 5 Return Optimum Portfolios in Bearish Period

\begin{tabular}{|c|c|c|c|c|c|c|c|c|c|c|c|c|c|}
\hline & Rp & BBCA & BMRI & ASII & BBRI & BDMN & PGAS & UNTR & TLKM & INDF & PTBA & INCO & AALI \\
\hline $7 / 31 / 2008$ & $9.3 \%$ & $22.2 \%$ & $14.4 \%$ & $17.1 \%$ & $19.6 \%$ & $18.1 \%$ & $-6.2 \%$ & $-6.2 \%$ & $5.5 \%$ & $-5.2 \%$ & $-16.8 \%$ & $-24.0 \%$ & $-25.9 \%$ \\
\hline $8 / 29 / 2008$ & $-1.4 \%$ & $5.0 \%$ & $-5.0 \%$ & $-7.8 \%$ & $-4.1 \%$ & $-2.7 \%$ & $4.5 \%$ & $-5.1 \%$ & $3.9 \%$ & $-1.1 \%$ & $6.2 \%$ & $-19.0 \%$ & $-18.0 \%$ \\
\hline $9 / 29 / 2008$ & $-9.1 \%$ & $-0.8 \%$ & $-6.2 \%$ & $-17.8 \%$ & $-7.7 \%$ & $-9.3 \%$ & $-14.7 \%$ & $-8.7 \%$ & $-10.6 \%$ & $-12.9 \%$ & $-35.5 \%$ & $-17.4 \%$ & $-27.9 \%$ \\
\hline $10 / 31 / 2008$ & $-26.2 \%$ & $-14.3 \%$ & $-41.1 \%$ & $-45.3 \%$ & $-36.1 \%$ & $-46.9 \%$ & $-35.6 \%$ & $-66.7 \%$ & $-23.3 \%$ & $-44.4 \%$ & $-41.4 \%$ & $-45.0 \%$ & $-53.3 \%$ \\
\hline $11 / 28 / 2008$ & $-6.8 \%$ & $0.0 \%$ & $-4.5 \%$ & $9.1 \%$ & $-1.4 \%$ & $1.0 \%$ & $31.4 \%$ & $26.2 \%$ & $8.3 \%$ & $-11.0 \%$ & $26.0 \%$ & $16.6 \%$ & $39.7 \%$ \\
\hline $12 / 30 / 2008$ & $16.5 \%$ & $20.4 \%$ & $35.9 \%$ & $3.4 \%$ & $34.6 \%$ & $18.1 \%$ & $1.1 \%$ & $10.7 \%$ & $17.9 \%$ & $-4.1 \%$ & $0.0 \%$ & $-2.0 \%$ & $16.0 \%$ \\
\hline $1 / 30 / 2009$ & $-3.0 \%$ & $-15.4 \%$ & $-10.1 \%$ & $23.2 \%$ & $-0.5 \%$ & $-26.6 \%$ & $18.3 \%$ & $14.8 \%$ & $-8.7 \%$ & $5.4 \%$ & $7.2 \%$ & $28.2 \%$ & $11.2 \%$ \\
\hline $2 / 27 / 2009$ & $-7.5 \%$ & $-14.5 \%$ & $-4.4 \%$ & $-13.1 \%$ & $-18.1 \%$ & $15.4 \%$ & $-13.6 \%$ & $5.9 \%$ & $0.0 \%$ & $-10.2 \%$ & $-2.7 \%$ & $-12.1 \%$ & $17.9 \%$ \\
\hline $3 / 31 / 2009$ & $17.3 \%$ & $31.9 \%$ & $25.0 \%$ & $26.1 \%$ & $12.8 \%$ & $19.0 \%$ & $13.2 \%$ & $26.2 \%$ & $19.8 \%$ & $6.8 \%$ & $-6.3 \%$ & $2.3 \%$ & $9.7 \%$ \\
\hline $4 / 30 / 2009$ & $22.7 \%$ & $8.1 \%$ & $27.6 \%$ & $26.3 \%$ & $38.1 \%$ & $32.3 \%$ & $20.9 \%$ & $33.3 \%$ & $4.0 \%$ & $36.2 \%$ & $40.7 \%$ & $53.9 \%$ & $12.1 \%$ \\
\hline $5 / 29 / 2009$ & $9.7 \%$ & $0.7 \%$ & $7.2 \%$ & $15.6 \%$ & $7.8 \%$ & $20.0 \%$ & $10.6 \%$ & $12.8 \%$ & $-5.1 \%$ & $39.1 \%$ & $18.4 \%$ & $5.1 \%$ & $12.7 \%$ \\
\hline $6 / 30 / 2009$ & $7.1 \%$ & $4.4 \%$ & $6.7 \%$ & $14.4 \%$ & $0.8 \%$ & $28.7 \%$ & $9.6 \%$ & $-2.0 \%$ & $0.7 \%$ & $6.2 \%$ & $3.1 \%$ & $15.3 \%$ & $-5.3 \%$ \\
\hline $7 / 31 / 2009$ & $16.1 \%$ & $7.1 \%$ & $31.5 \%$ & $23.1 \%$ & $15.9 \%$ & $0.0 \%$ & $11.1 \%$ & $30.2 \%$ & $19.3 \%$ & $20.4 \%$ & $17.2 \%$ & $3.6 \%$ & $14.5 \%$ \\
\hline
\end{tabular}


Table 6 Return Optimum Portfolios in Bullish Period

\begin{tabular}{|c|c|c|c|c|c|c|c|c|c|c|c|c|c|c|c|c|c|}
\hline & Rp & AALI & UNTR & PGAS & PTBA & ANTM & INCO & UNSP & INDF & BMRI & TLKM & BBCA & MEDC & ASII & BBRI & ISAT & BDMN \\
\hline $1 / 31 / 2005$ & $9.5 \%$ & $-3.2 \%$ & $25.3 \%$ & $34.2 \%$ & $8.2 \%$ & $5.5 \%$ & $0.9 \%$ & $11.3 \%$ & $8.7 \%$ & $0.8 \%$ & $-0.5 \%$ & $-3.4 \%$ & $25.3 \%$ & $4.7 \%$ & $-4.3 \%$ & $-4.3 \%$ & $-4.6 \%$ \\
\hline $2 / 28 / 2005$ & $7.5 \%$ & $3.3 \%$ & $6.1 \%$ & $6.9 \%$ & $0.6 \%$ & $18.1 \%$ & $22.7 \%$ & $18.8 \%$ & $6.9 \%$ & $-6.7 \%$ & $-7.8 \%$ & $13.9 \%$ & $-5.8 \%$ & $7.5 \%$ & $19.1 \%$ & $19.1 \%$ & $14.4 \%$ \\
\hline $3 / 31 / 2005$ & $2.0 \%$ & $29.0 \%$ & $-5.0 \%$ & $-16.5 \%$ & $-8.4 \%$ & $4.7 \%$ & $-4.9 \%$ & $7.3 \%$ & $24.7 \%$ & $-5.5 \%$ & $1.1 \%$ & $3.8 \%$ & $0.0 \%$ & $-2.8 \%$ & $-13.0 \%$ & $-13.0 \%$ & $-0.5 \%$ \\
\hline $4 / 29 / 2005$ & $-1.7 \%$ & $-10.0 \%$ & $2.6 \%$ & $14.3 \%$ & $2.0 \%$ & $-5.6 \%$ & $2.9 \%$ & $-6.8 \%$ & $-12.1 \%$ & $-6.4 \%$ & $-4.5 \%$ & $-9.6 \%$ & $5.1 \%$ & $0.5 \%$ & $-6.1 \%$ & $-6.1 \%$ & $-2.1 \%$ \\
\hline $5 / 31 / 2005$ & $6.7 \%$ & $1.4 \%$ & $11.0 \%$ & $6.7 \%$ & $0.6 \%$ & $10.6 \%$ & $-0.7 \%$ & $-2.4 \%$ & $17.6 \%$ & $3.8 \%$ & $8.8 \%$ & $13.0 \%$ & $22.3 \%$ & $10.9 \%$ & $8.4 \%$ & $8.4 \%$ & $3.8 \%$ \\
\hline $6 / 30 / 2005$ & $4.7 \%$ & $8.9 \%$ & $13.7 \%$ & $3.6 \%$ & $1.9 \%$ & $2.1 \%$ & $1.8 \%$ & $2.5 \%$ & $-8.3 \%$ & $-9.6 \%$ & $7.5 \%$ & $3.6 \%$ & $19.8 \%$ & $8.5 \%$ & $0.0 \%$ & $0.0 \%$ & $4.7 \%$ \\
\hline $7 / 29 / 2005$ & $5.3 \%$ & $3.8 \%$ & $19.5 \%$ & $12.2 \%$ & $-1.3 \%$ & $1.0 \%$ & $6.0 \%$ & $-1.2 \%$ & $-0.9 \%$ & $7.3 \%$ & $11.0 \%$ & $1.4 \%$ & $-15.2 \%$ & $3.9 \%$ & $10.3 \%$ & $10.3 \%$ & $10.9 \%$ \\
\hline $8 / 31 / 2005$ & $-4.8 \%$ & $-1.2 \%$ & $-12.9 \%$ & $10.9 \%$ & $10.8 \%$ & $-7.2 \%$ & $4.0 \%$ & $-7.4 \%$ & $-27.5 \%$ & $-14.9 \%$ & $-7.2 \%$ & $-6.2 \%$ & $3.9 \%$ & $-23.1 \%$ & $-19.5 \%$ & $-19.5 \%$ & $-19.6 \%$ \\
\hline 9/30/2005 & $6.2 \%$ & $25.8 \%$ & $0.0 \%$ & $16.8 \%$ & $-6.3 \%$ & $21.1 \%$ & $-0.6 \%$ & $-6.7 \%$ & $-7.6 \%$ & $5.8 \%$ & $3.9 \%$ & $0.7 \%$ & $9.0 \%$ & $-3.9 \%$ & $4.9 \%$ & $4.9 \%$ & $-10.6 \%$ \\
\hline $10 / 31 / 2005$ & $2.8 \%$ & $5.4 \%$ & $-4.5 \%$ & $29.3 \%$ & $9.2 \%$ & $-5.5 \%$ & $-6.8 \%$ & $11.4 \%$ & $12.3 \%$ & $-9.0 \%$ & $-6.5 \%$ & $-6.5 \%$ & $-2.8 \%$ & $-4.6 \%$ & $-9.3 \%$ & $-9.3 \%$ & $-2.5 \%$ \\
\hline $11 / 30 / 2005$ & $4.2 \%$ & $1.9 \%$ & $-2.7 \%$ & $32.4 \%$ & $-5.1 \%$ & $10.7 \%$ & $-11.4 \%$ & $3.8 \%$ & $3.7 \%$ & $-2.3 \%$ & $10.0 \%$ & $2.3 \%$ & $-5.7 \%$ & $-2.2 \%$ & $21.4 \%$ & $21.4 \%$ & $-0.6 \%$ \\
\hline $12 / 30 / 2005$ & $4.2 \%$ & $-10.9 \%$ & $2.1 \%$ & $-3.5 \%$ & $6.5 \%$ & $25.4 \%$ & $2.7 \%$ & $2.5 \%$ & $7.1 \%$ & $27.1 \%$ & $7.3 \%$ & $3.0 \%$ & $1.5 \%$ & $12.1 \%$ & $1.7 \%$ & $1.7 \%$ & $21.8 \%$ \\
\hline $1 / 31 / 2006$ & $8.3 \%$ & $3.1 \%$ & $4.1 \%$ & $20.3 \%$ & $8.9 \%$ & $19.6 \%$ & $10.6 \%$ & $1.2 \%$ & $-3.3 \%$ & $8.5 \%$ & $6.8 \%$ & $6.6 \%$ & $15.6 \%$ & $2.0 \%$ & $12.4 \%$ & $12.4 \%$ & $-2.1 \%$ \\
\hline $2 / 28 / 2006$ & $6.7 \%$ & $16.8 \%$ & $3.9 \%$ & $16.3 \%$ & $4.6 \%$ & $-5.8 \%$ & $7.2 \%$ & $40.5 \%$ & $-4.5 \%$ & $-9.0 \%$ & $-1.6 \%$ & $-0.7 \%$ & $5.8 \%$ & $-5.8 \%$ & $-4.4 \%$ & $-4.4 \%$ & $-8.1 \%$ \\
\hline $3 / 31 / 2006$ & $8.3 \%$ & $5.1 \%$ & $13.2 \%$ & $3.6 \%$ & $0.0 \%$ & $8.1 \%$ & $9.9 \%$ & $15.3 \%$ & $6.0 \%$ & $4.3 \%$ & $11.3 \%$ & $16.0 \%$ & $0.6 \%$ & $14.8 \%$ & $20.0 \%$ & $20.0 \%$ & $12.3 \%$ \\
\hline $4 / 28 / 2006$ & $20.2 \%$ & $6.5 \%$ & $21.1 \%$ & $24.0 \%$ & $46.3 \%$ & $32.2 \%$ & $16.6 \%$ & $23.5 \%$ & $27.0 \%$ & $13.6 \%$ & $9.4 \%$ & $4.8 \%$ & $15.7 \%$ & $6.2 \%$ & $18.6 \%$ & $18.6 \%$ & $7.3 \%$ \\
\hline $5 / 31 / 2006$ & $-4.3 \%$ & $-1.5 \%$ & $-0.9 \%$ & $-1.2 \%$ & $11.7 \%$ & $-22.6 \%$ & $-1.2 \%$ & $14.3 \%$ & $-16.8 \%$ & $-12.0 \%$ & $-6.6 \%$ & $-6.3 \%$ & $-17.2 \%$ & $-18.0 \%$ & $-14.6 \%$ & $-14.6 \%$ & $-10.7 \%$ \\
\hline $6 / 30 / 2006$ & $-1.9 \%$ & $0.0 \%$ & $0.0 \%$ & $-8.2 \%$ & $-6.0 \%$ & $3.9 \%$ & $-1.0 \%$ & $-7.3 \%$ & $-6.4 \%$ & $1.8 \%$ & $4.3 \%$ & $0.0 \%$ & $-6.3 \%$ & $-0.5 \%$ & $3.8 \%$ & $3.8 \%$ & $-13.6 \%$ \\
\hline $7 / 31 / 2006$ & $9.2 \%$ & $28.5 \%$ & $3.7 \%$ & $4.9 \%$ & $4.0 \%$ & $12.4 \%$ & $2.0 \%$ & $20.2 \%$ & $19.3 \%$ & $2.3 \%$ & $1.4 \%$ & $1.8 \%$ & $2.0 \%$ & $-1.5 \%$ & $4.3 \%$ & $4.3 \%$ & $6.9 \%$ \\
\hline $8 / 31 / 2006$ & $6.1 \%$ & $10.2 \%$ & $2.7 \%$ & $7.2 \%$ & $3.8 \%$ & $3.8 \%$ & $10.3 \%$ & $-10.3 \%$ & $13.3 \%$ & $19.3 \%$ & $6.0 \%$ & $9.0 \%$ & $-5.3 \%$ & $15.6 \%$ & $1.8 \%$ & $1.8 \%$ & $15.3 \%$ \\
\hline 9/29/2006 & $2.2 \%$ & $-1.1 \%$ & $5.2 \%$ & $-4.7 \%$ & $-0.7 \%$ & $1.9 \%$ & $4.5 \%$ & $-8.3 \%$ & $5.0 \%$ & $10.7 \%$ & $7.0 \%$ & $6.0 \%$ & $-3.5 \%$ & $12.2 \%$ & $12.6 \%$ & $12.6 \%$ & $8.2 \%$ \\
\hline $10 / 31 / 2006$ & $5.7 \%$ & $7.1 \%$ & $8.3 \%$ & $-5.4 \%$ & $2.2 \%$ & $26.4 \%$ & $14.3 \%$ & $-2.3 \%$ & $6.4 \%$ & $17.2 \%$ & $-0.6 \%$ & $-3.6 \%$ & $-4.3 \%$ & $7.6 \%$ & $0.0 \%$ & $0.0 \%$ & $12.3 \%$ \\
\hline $11 / 30 / 2006$ & $3.9 \%$ & $9.2 \%$ & $-1.5 \%$ & $-4.4 \%$ & $-5.8 \%$ & $8.6 \%$ & $4.6 \%$ & $-2.3 \%$ & $5.3 \%$ & $1.8 \%$ & $17.9 \%$ & $14.0 \%$ & $-2.3 \%$ & $19.0 \%$ & $9.2 \%$ & $9.2 \%$ & $5.0 \%$ \\
\hline $12 / 28 / 2006$ & $6.9 \%$ & $18.3 \%$ & $1.6 \%$ & $6.4 \%$ & $8.5 \%$ & $6.0 \%$ & $12.7 \%$ & $15.5 \%$ & $-3.6 \%$ & $4.5 \%$ & $2.0 \%$ & $-1.9 \%$ & $9.2 \%$ & $-1.6 \%$ & $-3.7 \%$ & $-3.7 \%$ & $8.0 \%$ \\
\hline $1 / 31 / 2007$ & $-1.3 \%$ & $4.8 \%$ & $3.1 \%$ & $-19.0 \%$ & $-11.3 \%$ & $-2.5 \%$ & $6.5 \%$ & $4.1 \%$ & $25.2 \%$ & $-11.2 \%$ & $-6.4 \%$ & $-1.9 \%$ & $-3.5 \%$ & $-5.4 \%$ & $2.9 \%$ & $2.9 \%$ & $-12.6 \%$ \\
\hline $2 / 28 / 2007$ & $1.4 \%$ & $-4.9 \%$ & $3.0 \%$ & $-4.8 \%$ & $5.6 \%$ & $16.7 \%$ & $17.6 \%$ & $11.9 \%$ & $-7.7 \%$ & $-9.7 \%$ & $-5.8 \%$ & $-3.4 \%$ & $6.6 \%$ & $-5.4 \%$ & $-10.4 \%$ & $-10.4 \%$ & $-2.5 \%$ \\
\hline $3 / 30 / 2007$ & $8.0 \%$ & $0.4 \%$ & $6.5 \%$ & $4.5 \%$ & $4.5 \%$ & $30.2 \%$ & $40.1 \%$ & $1.8 \%$ & $-2.6 \%$ & $7.5 \%$ & $10.7 \%$ & $3.6 \%$ & $-2.1 \%$ & $-6.0 \%$ & $6.3 \%$ & $6.3 \%$ & $13.9 \%$ \\
\hline $4 / 30 / 2007$ & $14.3 \%$ & $25.0 \%$ & $6.8 \%$ & $12.3 \%$ & $13.0 \%$ & $31.6 \%$ & $11.9 \%$ & $25.2 \%$ & $7.9 \%$ & $23.0 \%$ & $6.6 \%$ & $3.9 \%$ & $-1.4 \%$ & $9.1 \%$ & $4.0 \%$ & $4.0 \%$ & $-1.5 \%$ \\
\hline $5 / 31 / 2007$ & $2.4 \%$ & $-4.1 \%$ & $-4.4 \%$ & $-2.4 \%$ & $34.6 \%$ & $-10.3 \%$ & $-9.5 \%$ & $5.6 \%$ & $5.5 \%$ & $5.7 \%$ & $-9.0 \%$ & $-0.9 \%$ & $1.4 \%$ & $13.9 \%$ & $16.2 \%$ & $16.2 \%$ & $8.5 \%$ \\
\hline 6/29/2007 & $1.7 \%$ & $-8.9 \%$ & $9.3 \%$ & $-7.8 \%$ & $24.8 \%$ & $-10.4 \%$ & $0.9 \%$ & $0.0 \%$ & $17.1 \%$ & $-3.8 \%$ & $3.1 \%$ & $3.8 \%$ & $-1.4 \%$ & $3.0 \%$ & $-5.7 \%$ & $-5.7 \%$ & $-1.4 \%$ \\
\hline 7/31/2007 & $8.0 \%$ & $11.6 \%$ & $4.2 \%$ & $-2.1 \%$ & $1.5 \%$ & $7.6 \%$ & $3.1 \%$ & $21.7 \%$ & $-1.2 \%$ & $12.8 \%$ & $13.7 \%$ & $15.6 \%$ & $21.3 \%$ & $10.9 \%$ & $9.6 \%$ & $9.6 \%$ & $22.5 \%$ \\
\hline $8 / 31 / 2007$ & $-6.8 \%$ & $-6.8 \%$ & $-5.8 \%$ & $10.8 \%$ & $-13.5 \%$ & $-16.7 \%$ & $-5.8 \%$ & $-22.7 \%$ & $-7.0 \%$ & $-7.8 \%$ & $-3.1 \%$ & $-4.8 \%$ & $-8.8 \%$ & $-4.8 \%$ & $-0.8 \%$ & $-0.8 \%$ & $-4.7 \%$ \\
\hline 9/28/2007 & $12.0 \%$ & $17.5 \%$ & $1.2 \%$ & $17.6 \%$ & $13.9 \%$ & $23.3 \%$ & $17.8 \%$ & $22.9 \%$ & $3.8 \%$ & $8.5 \%$ & $1.4 \%$ & $2.5 \%$ & $6.4 \%$ & $7.8 \%$ & $5.6 \%$ & $5.6 \%$ & $5.0 \%$ \\
\hline $10 / 31 / 2007$ & $25.2 \%$ & $33.9 \%$ & $33.5 \%$ & $16.2 \%$ & $38.2 \%$ & $20.7 \%$ & $42.0 \%$ & $29.2 \%$ & $14.0 \%$ & $7.1 \%$ & $-2.3 \%$ & $18.7 \%$ & $12.7 \%$ & $33.0 \%$ & $17.4 \%$ & $17.4 \%$ & $2.4 \%$ \\
\hline $11 / 30 / 2007$ & $12.3 \%$ & $13.1 \%$ & $2.7 \%$ & $20.7 \%$ & $33.7 \%$ & $39.6 \%$ & $4.5 \%$ & $10.6 \%$ & $14.8 \%$ & $-6.0 \%$ & $-5.6 \%$ & $-2.7 \%$ & $15.5 \%$ & $-2.3 \%$ & $0.6 \%$ & $0.6 \%$ & $-4.0 \%$ \\
\hline $12 / 28 / 2007$ & $0.2 \%$ & $10.0 \%$ & $-3.1 \%$ & $-9.2 \%$ & $-0.8 \%$ & $-4.3 \%$ & $2.1 \%$ & $3.4 \%$ & $2.0 \%$ & $-1.4 \%$ & $0.0 \%$ & $2.8 \%$ & $-4.6 \%$ & $9.2 \%$ & $-5.1 \%$ & $-5.1 \%$ & $-3.6 \%$ \\
\hline $1 / 31 / 2008$ & $-1.5 \%$ & $7.9 \%$ & $22.0 \%$ & $-12.7 \%$ & $-5.0 \%$ & $-20.1 \%$ & $-17.4 \%$ & $11.0 \%$ & $9.7 \%$ & $-5.0 \%$ & $-8.9 \%$ & $-2.7 \%$ & $-21.4 \%$ & $-0.2 \%$ & $-5.4 \%$ & $-5.4 \%$ & $-10.0 \%$ \\
\hline $2 / 29 / 2008$ & $4.3 \%$ & $4.6 \%$ & $-0.4 \%$ & $3.0 \%$ & $0.4 \%$ & $14.7 \%$ & $18.9 \%$ & $1.0 \%$ & $3.5 \%$ & $-1.5 \%$ & $5.9 \%$ & $0.7 \%$ & $1.9 \%$ & $2.2 \%$ & $2.9 \%$ & $2.9 \%$ & $6.2 \%$ \\
\hline $3 / 31 / 2008$ & $-13.1 \%$ & $-18.2 \%$ & $-5.3 \%$ & $2.5 \%$ & $-12.2 \%$ & $-18.3 \%$ & $-25.9 \%$ & $-30.2 \%$ & $-20.5 \%$ & $-3.8 \%$ & $-1.5 \%$ & $-9.1 \%$ & $-19.4 \%$ & $-12.9 \%$ & $-12.5 \%$ & $-12.5 \%$ & $-9.8 \%$ \\
\hline $4 / 30 / 2008$ & $-4.7 \%$ & $-8.3 \%$ & $-4.0 \%$ & $-14.5 \%$ & $5.5 \%$ & $4.5 \%$ & $-5.0 \%$ & $-9.6 \%$ & $-2.2 \%$ & $-8.7 \%$ & $-8.3 \%$ & $-7.7 \%$ & $18.0 \%$ & $-17.5 \%$ & $-5.6 \%$ & $-5.6 \%$ & $-17.4 \%$ \\
\hline $5 / 30 / 2008$ & $11.4 \%$ & $11.6 \%$ & $19.9 \%$ & $15.7 \%$ & $37.7 \%$ & $-7.1 \%$ & $-8.3 \%$ & $21.1 \%$ & $23.1 \%$ & $0.9 \%$ & $-8.5 \%$ & $-7.5 \%$ & $28.7 \%$ & $5.0 \%$ & $-2.5 \%$ & $-2.5 \%$ & $0.0 \%$ \\
\hline $6 / 30 / 2008$ & $-3.5 \%$ & $11.7 \%$ & $-15.9 \%$ & $-7.1 \%$ & $12.3 \%$ & $-2.3 \%$ & $-0.8 \%$ & $-3.6 \%$ & $-14.3 \%$ & $-7.5 \%$ & $-9.9 \%$ & $-10.8 \%$ & $-6.4 \%$ & $-8.3 \%$ & $-12.1 \%$ & $-12.1 \%$ & $-17.5 \%$ \\
\hline
\end{tabular}

The efficient portfolio can be proved by using linear regression which aims to show the correlation between portfolio return with expected return of each stock. In the bearish period, all the stocks in the portfolio have the p-value less than 5\% except AALI.

According to linear regression, it can be shown the p-value of each stock from both periods; bearish and bullish are less than 5\%. In the bearish period, all the stocks in the portfolio have p-value less than 5\% except AALI. While in the bullish period, the stock of portfolio has p-value are less than $5 \%$. In this case, the writers reject $\mathrm{H} 0$ because there is the correlation between portfolio return with stock return. Table 7 shows p-value in each period, the bearish and the bullish period.

Table 7 P-Value in Bearish and Bullish Period

\begin{tabular}{|c|c|c|c|c|c|c|c|}
\hline Bearish & Low & High & P-value & Bullish & Low & High & P-value \\
\hline BBCA & 0.275636 & 1.136016 & $0.40888 \%$ & & 0.218493 & 0.525644 & $0.0016 \%$ \\
\hline BMRI & 0.497859 & 0.750319 & $0.00003 \%$ & & 0.289487 & 0.629787 & $0.0003 \%$ \\
\hline SII & 397 & 0779669 & 0 03899\% & PTBA & 法 & $\begin{array}{l}0.410963 \\
0.47581\end{array}$ & $0.1168 \%$ \\
\hline BBRI & & & & ANTM & 0.218805 & 0.430752 & $\begin{array}{l}0.0030 \% \\
0.0000 \%\end{array}$ \\
\hline & 0.468362 & 0.803163 & $0.00043 \%$ & INCO & 0.212463 & 0.485325 & $0.0007 \%$ \\
\hline DMN & 0.230600 & 0.730655 & $0.14102 \%$ & UNSP & 0.242956 & 0.471583 & $0.0000 \%$ \\
\hline PGAS & 0.037427 & 0.875676 & $3.53868 \%$ & INDF & 0.167302 & 0.464511 & $0.0108 \%$ \\
\hline UNTR & 0.165418 & 0.633454 & $0.31724 \%$ & BMRI & 0.176601 & 0.563904 & $0.0399 \%$ \\
\hline TLKM & 0.378168 & 1.313727 & $0.21576 \%$ & TLKM & 0.028310 & 0.609088 & $3.2289 \%$ \\
\hline INDF & 0.254412 & 0.760417 & $0.10384 \%$ & BBCA & $\begin{array}{l}0.296122 \\
0.152156\end{array}$ & $\begin{array}{l}0.798066 \\
0.474180\end{array}$ & $0.0077 \%$ \\
\hline PTBA & 0.042988 & 0.681191 & $2.96382 \%$ & ASII & 0.257824 & 0.586412 & $0.0006 \%$ \\
\hline INCO & 0.026479 & 0.615737 & 3.53 & BBRI & 0.227048 & 0.581978 & $0.0041 \%$ \\
\hline AALI & -0.054829 & 0.588645 & $9.51063 \%$ & DMNA & 0.227048 & 0.581978 & $0.0041 \%$ \\
\hline & & & & DIVIN & .138409 & 0.519395 & $0.1193 \%$ \\
\hline
\end{tabular}


From the result of hypothesis, there are correlations between portfolio return with the stock return in both periods. As shown on Table 7, the majority P-value of each stock is below on 5\% except AALI. In the bullish period, all P-value of each stock is below on 5\%. The construction of the optimum portfolio has the higher return than LQ-45 index return in both periods. Table 8 and Table 9 show the return and risk of LQ-45 index in both periods.

Table 8 The Return and Risk of LQ-45 index in Bearish Period

\begin{tabular}{|c|c|c|}
\hline \multicolumn{3}{|c|}{ BEARISH } \\
\hline Date & Last Price & Return \\
\hline $7 / 31 / 2008$ & 481.30 & $-2.80 \%$ \\
\hline $8 / 29 / 2008$ & 449.66 & $-6.57 \%$ \\
\hline $9 / 29 / 2008$ & 369.14 & $-17.91 \%$ \\
\hline $10 / 31 / 2008$ & 241.35 & $-34.62 \%$ \\
\hline $11 / 28 / 2008$ & 241.50 & $6.00 \%$ \\
\hline $12 / 30 / 2008$ & 270.23 & $11.90 \%$ \\
\hline $1 / 30 / 2009$ & 262.56 & $-2.84 \%$ \\
\hline $2 / 27 / 2009$ & 249.01 & $-5.16 \%$ \\
\hline $3 / 31 / 2009$ & 283.08 & $13.68 \%$ \\
\hline $4 / 30 / 09$ & 341.73 & $20.72 \%$ \\
\hline $5 / 29 / 09$ & 373.07 & $9.17 \%$ \\
\hline $6 / 30 / 09$ & 392.12 & $5.11 \%$ \\
\hline $7 / 31 / 09$ & 454.42 & $15.89 \%$ \\
\hline RETURN & & $0.51 \%$ \\
\hline $\begin{array}{l}\text { STANDARD DE } \\
\text { VARIANCE }\end{array}$ & IATION ( $\sigma$ & $\begin{array}{r}15.06 \% \\
0.02 \%\end{array}$ \\
\hline Bearsih Period & $\mathbf{E}(\mathbf{R i})$ & $\sigma$ \\
\hline Portfolio G & $4.20 \%$ & $6.90 \%$ \\
\hline LQ-45 Index & $2.20 \%$ & $6.10 \%$ \\
\hline
\end{tabular}

Table 9 The Return and Risk of LQ-45 index in Bullish Period

\begin{tabular}{|c|c|c|}
\hline & JLLISH & \\
\hline Date & Last Price & Return \\
\hline $1 / 31 / 2005$ & 227.73 & $4.90 \%$ \\
\hline $2 / 28 / 2005$ & 233.07 & $2.34 \%$ \\
\hline $3 / 31 / 2005$ & 233.85 & $0.34 \%$ \\
\hline $4 / 29 / 2005$ & 223.14 & $-4.58 \%$ \\
\hline $5 / 31 / 2005$ & 237.79 & $6.57 \%$ \\
\hline $6 / 30 / 2005$ & 246.57 & $3.69 \%$ \\
\hline $7 / 29 / 2005$ & 260.87 & $5.80 \%$ \\
\hline $8 / 31 / 2005$ & 230.56 & $-11.62 \%$ \\
\hline $9 / 30 / 2005$ & 235.81 & $2.28 \%$ \\
\hline $10 / 31 / 2005$ & 227.83 & $-3.38 \%$ \\
\hline $11 / 30 / 2005$ & 237.33 & $4.17 \%$ \\
\hline $12 / 30 / 2005$ & 254.35 & $7.17 \%$ \\
\hline 1/31/2006 & 271.63 & $6.80 \%$ \\
\hline $2 / 28 / 2006$ & 270.42 & -0.44 \\
\hline $3 / 31 / 2006$ & 292.57 & 8.19 \\
\hline 4/28/2006 & 325.1 & 11.12 \\
\hline $5 / 31 / 2006$ & 294.05 & -9.55 \\
\hline $6 / 30 / 2006$ & 289.73 & -1.47 \\
\hline $7 / 31 / 2006$ & 299.07 & 3.22 \\
\hline $8 / 31 / 2006$ & 317.61 & 6.2 \\
\hline $9 / 29 / 2006$ & 336.47 & 5.94 \\
\hline $10 / 31 / 2006$ & 345.85 & 2.79 \\
\hline $11 / 30 / 2006$ & 376.93 & 8.99 \\
\hline $12 / 28 / 2006$ & 388.29 & 3.01 \\
\hline $1 / 31 / 2007$ & 377.1 & -2.88 \\
\hline $2 / 28 / 2007$ & 367.81 & -2.46 \\
\hline $3 / 30 / 2007$ & 390.92 & 6.28 \\
\hline $4 / 30 / 2007$ & 424.57 & 8.61 \\
\hline $5 / 31 / 2007$ & 433.45 & 2.09 \\
\hline $6 / 29 / 2007$ & 442.12 & 2 \\
\hline $7 / 31 / 2007$ & 487.59 & 10.28 \\
\hline $8 / 31 / 2007$ & 457.96 & -6.08 \\
\hline $9 / 28 / 2007$ & 498.71 & 8.9 \\
\hline $10 / 31 / 2007$ & 575.51 & 15.4 \\
\hline $11 / 30 / 2007$ & 591.87 & 2.84 \\
\hline $12 / 28 / 2007$ & 599.82 & 1.34 \\
\hline $1 / 31 / 2008$ & 564.32 & -5.92 \\
\hline $2 / 29 / 2008$ & 590.77 & 4.69 \\
\hline $3 / 31 / 2008$ & 525.41 & -11.06 \\
\hline $4 / 30 / 2008$ & 493.46 & -6.08 \\
\hline $5 / 30 / 2008$ & 518.36 & 5.04 \\
\hline $6 / 30 / 2008$ & 495.17 & -4.47 \\
\hline RETURN & & 2.17 \\
\hline STANDARD DE & TION $(\sigma)$ & 6.14 \\
\hline VARIANCE & & 0.0038 \\
\hline Bullish Period & E(Ri) & $\boldsymbol{\sigma}$ \\
\hline Portfolio J & $4.5 \%$ & $4.2 \%$ \\
\hline LQ-45 Index & $2.2 \%$ & $6.1 \%$ \\
\hline
\end{tabular}

\section{CONCLUSIONS}

Constructing optimum portfolio with Mean-Variance (consistent with Markowitz theory) combine with linear programming can be applied in LQ-45 stocks portfolio. The expected return of optimum portfolio in both period can beat the LQ-45 index return. The standard deviation of the optimum portfolio is lower than the LQ-45 index. The Standard Deviation $(\sigma)$ is a proxy of risk. In the bearish period, the composition of the optimum portfolio is dominated by the banking sector and manufacture sector. 
The government usually will decrease the interest rate when the market crash or in turbulence period. Therefore, it will give good impact to the banking sector and manufacture sector. In the bullish period, the optimum portfolio is dominated by the commodity stocks. The demand of raw material especially commodity will increase in the stable period. It will give good impact to commodity sector because of the higher demand.

This research can be continued by finding out whether the optimum portfolio exceeds the market return. Furthermore, the research can be continued by predicting forward return from the optimum portfolio. Despite the success of describing an optimum LQ-45 portfolio, the research has several constraints such as in selecting the portfolio stocks. During the research period $2005-2011$, there are only 16 selected stocks based on stocks listed in LQ-45. The other limitation, there are more factors can affect the return such as market risk like interest rate risk, foreign exchange risk, and political risk.

\section{REFERENCES}

Bernstein, P. L., \& Damodaran, A. (1998). Investment Management. Wiley Frontier in Finance.

Bodie, Z., Kane, A., \& Marcus, A. J. (2009). Investments ( $8^{\text {th }}$ ed). McGraw Hill Higher Education.

Brigham, E. F., \& Daves, P. F. (2010). Intermediate Financial Management $\left(10^{\text {th }}\right.$ ed). South Western: Thomson Learning

Chen, Z., Ibbotson, R. G., \& Hu, W. (2009). Liquidity as an investment style (SSRN Working Paper). Retrieved from http://ssrn.com/abstract $=1675108$.

Fabozzi, F. J., \& Vardharaj, R. (2002a). Multifactor Equity Risk Models. In Frank J. Fabozzi and Harry M. Markowitz (eds). The Theory and Practice of Investment Management. New York: John Wiley \& Sons.

Fabozzi J. F., Gupta, F., Markowitz, H. M. (2002b). The Legacy of Modern Portfolio Theory. The Journal of Investing, 7-22.

Gallati, R. (2003). Risk Management and Capital Adequacy. New York: McGraw-Hill.

Markowitz, H. M. (1952). Portfolio Selection. The Journal of Finance, 7(1), 77-91.

Markowitz, H. M. (1959). Portfolio Selection: Efficient Diversification of Investment. New York: John Wiley Sons.

Markowitz, H. M., \& Perold, A. F. (2011). Portfolio Analysis with actors and Scenarios. The Journal of Finance, 36(4), 871-877.

Reilly, F. K., \& Brown, K. C. (2009). Investment Analysis and Portfolio Management $\left(9^{\text {th }}\right.$ ed). Texas: South-Western Cengage Learning. 